\title{
PENERAPAN SUPERVISI KLINIK DAN MANAJEMENT PEMBELAJARAN SEBAGAI UPAYA MENINGKATKAN KEMAMPUAN GURU - GURU SD NEGERI 1 BLAHBATUH DALAM MELAKSANAKAN PROSES PEMBELAJARAN YANG BERKUALITAS
}

\author{
Ketut Natakesuma \\ SD Negeri 1 Blahbatuh \\ email : natakesumakt8@gmail.com
}

\begin{abstract}
Abstrak
Penelitian ini dilaksanakan di SD Negeri 1 Blahbatuh. Tujuan penelitian ini adalah untuk mengetahui apakah supervisi klinik dapat membantu meningkatkan kemampuan guru-guru SD Negeri 1 Blahbatuh melaksanakan proses pembelajaran. Langkah-langkah supervisi klinik yang dilakukan adalah memberi bimbingan, melakukan tanya jawab, memberi kesempatan diskusi. Metode pengumpulan data yang digunakan adalah observasi. Metode analisis data yang digunakan adalah analisis deskriptif data kuantitatif. Untuk pengecekan validitas internal data digunakan masukan dari para informan, untuk pengecekan validitas external data digunakan landasan-landasan hukum yang ada, sedangkan untuk pengecekan reliabilitas digunakan ketepatan informan. Hasil yang didapat dari penelitian ini adalah: guru-guru SD Negeri 1 Blahbatuh yang nilai awalnya baru mencapai rata-rata 48,12 pada siklus I meningkat menjadi 56,87 dan pada siklus II meningkat menjadi 61,25. Simpulan yang diperoleh dalam penelitian ini adalah bahwa Supervisi Klinik dengan langkah-langkah seperti bimbingan, tanya jawab, diskusi, unjuk kerja, studi dokumen dapat meningkatkan kemampuan guru-guru SD Negeri1 Blahbatuh dalam melaksanakan proses pembelajaran yang efektif di SD Negeri 1 Blahbatuh Tahun Pelajaran $2017 / 2018$.
\end{abstract}

Kata kunci: Supervisi Klinik, Kemampuan Proses Pembelajaran

\begin{abstract}
This research was conducted in SD 1 Blahbatuh. The purpose of this study was to find out whether clinical supervision can help improve the ability of SD 1 Blahbatuh elementary school teachers to carry out the learning process. The steps of clinical supervision are to provide guidance, conduct question and answer, provide opportunities for discussion. The data collection method used observation. The data analysis method used was descriptive analysis of quantitative data. To check the internal validity of the data used input from the informants, to check the external data validity used legal foundations, while for checking reliability used the accuracy of the informant. The results obtained from this study were: elementary school teachers 1 Blahbatuh whose initial value only reached an average of 48.12 in the first cycle increased to 56.87 and in the second cycle increased to 61.25 . The conclusion obtained in this study is that Clinical Supervision with steps such as guidance, question and answer, discussion, performance, document study can improve the ability of elementary school teachers in Blahbatuh to carry out effective learning processes in SD 1 Blahbatuh in 2017 / 2018.
\end{abstract}

Keywords: Clinical Supervision, Learning Process Capability 


\section{Pendahuluan}

Tertekannya masyarakat Indonesia dalam waktu yang lama telah membuat rakyat tergugah dan memunculkan arus reformasi yang dasyat dan mendesak pemerintah Indonesia dan orang-orang yang berkuasa di Republik ini membuat perubahan mendasar di berbagai bidang. Landasan-landasan konstitusi yang lahir mengikuti arus reformasi seperti UU No. 22 tahun 1999 tentang Pemerintah Daerah, PP No. 25 tahun 2000 tentang Kewenangan Pemerintah dan Kewenangan Propinsi sebagai Daerah Otonum, serta UU Pendidikan No. 20 tahun 2003 tentang Sistim Pendidikan Nasional yang dibarengi oleh PP No. 19 tahun 2005 yang telah diganti dengan PP No. 32 Tahun 2013 memaksa Pemerintah Indonesia berbalik haluan dalam mengelola pendidikan Indonesia dari sistim lama ke sistim baru.

Data temuan Bank Dunia (Sujanto, 2007: 33) menyatakan bahwa kemampuan manajemen para kepala sekolah pada umumnya rata-rata rendah, terutama di sekolah-sekolah negeri. Kemampuan manajemen yang rendah mengarah pada guru yang apatis dan tidak mau melaksanakan tugas dengan baik dan tidak mau membuat perencanaan program karena perencanaan merupakan salah satu dari keempat unsur manajemen yaitu: perencanaan (planning), pengorganisasian (organizing), pelaksanaan (actuating) dan pengawasan (controlling). (Tjokroamidjojo, 2001: 34). Dari hal tersebut, sebagai seorang pengawas sekolah haruslah giat bekerja untuk memperbaiki keadaan yang ada.

Seorang pengawas sekolah harus pandai dalam melaksanakan tugas agar pelaksanaan proses pembelajaran sesuai standar yang diharapkan sehingga perlu dilihat baik-baik oleh pengawas sekolah dalam pelaksanaannya di lapangan.

Fakta dan data lapangan yang merupakan kelemahan-kelemahan guru dalam membuat perencanaan telah terdeteksi pada pengawasan rutin tahun ajaran sebelumnya. Salah satu contohnya adalah kepala-kepala sekolah meminta pada pengawas agar ikut serta mengawasi guru-guru mereka agar lebih giat dalam melaksanakan tugas. Hal ini merupakan pertanda sakitnya dunia pendidikan di salah satu bagian dari Indonesia tercinta ini. Apabila sakit ini juga merupakan sakit guru-guru pada umumnya di Indonesia maka kemajuan pendidikan di Indonesia akan berjalan sangat lamban dan tidak sesuai dengan harapan pemerintah pusat maupun harapan kita semua.

Guru-guru diharapkan mampu melaksanakan pembelajaran yang baik secara mandiri dalam pelaksanaan tugasnya. Kemandirian adalah dapat mengatasi kepentingan sendiri tanpa bergantung pada orang lain (Kamus Besar Bahasa Indonesia, 513). Guru-guru biasanya meminjam program temannya dalam membuat perencanaan program tapi yang baik adalah tidak menuruti begitu saja contoh tersebut tanpa membuat pengembangan-pengembangan sesuai kemampuan sendiri yang memenuhi prinsip-prinsip otonomi, akuntabilitas, jaminan mutu, dan evaluasi yang transparan (Pasal 5, Ayat 2 UU No. 20 Tahun 2003).

Lemahnya pelaksanaan pembelajaran di kelas yang diakibatkan rehdanya kemampuan guru-guru melaksanakan proses pembelajaran yang baik dan benar adalah bumerang bagi kemajuan pendidikan di Indonesia mengingat tuntutan Standar Proses sesuai Permen No. 41 tahun 2007 sesuai kurikulum sebelumnya dan permen 65 Tahun 2013 serta petunjuk pengembangannya yang tertuang dalam Permen 81A Tahun 2013 adalah agar guru-guru lebih profesional serta adanya keterlibatan aktif berbagai pelaku pendidikan termasuk pula adanya proses pembelajaran yang inovatif dan accountable (Umaedi, Hadiyanto, Siswantari, 2007: 4). Ketidakmampuan guru-guru melaksanakan proses pembelajaran dengan baik perlu dipertanyakan sebab-sebabnya dan perlu dicarikan jalan pemecahannya. Oleh karenanya penelitian ini penting untuk dilakukan. Menurut Tanama (2016) Supervisi klinis merupakan jawaban untuk mengatasi permasalahan guru dalam pembelajaran. Supervisi klinis sama halnya dengan mendiagnosis orang sakit, maka guru juga mendapat diagnosis dalam proses belajar mengajar. Diagnosa dilakukan untuk menemukan aspek-aspek mana yang membuat guru itu tidak dapat mengajar dengan baik, kemudian aspekaspek tersebut diperhatikan satupersatu secara intensif. Dalam supervisi klinis cara pemberian obatnya dilakukan setelah supervisor mengadakan pengamatan secara langsung terhadap cara guru mengajar dengan 
menggunakan diskusi balikan antara supervisor dan guru yang bersangkutan. Diskusi balikan adalah diskusi yang bertujuan untuk memperoleh balikan tentang kebaikan maupun kelemahan yang terdapat selama guru mengajar serta bagaimana usaha untuk memperbaikinya. Menurut Himdani (2017) supervisi klinis adalah bantuan profesional yang diberikan pada guru yang mengalami masalah dalam pembelajaran/layanan agar guru yang bersangkutan dapat mengatasi masalahnya dengan langkah yang sistematis. Peran supervisi untuk meningkatkan mutu layanan. Rangkaian manajemen disekolah memang sangat besar, karna itu supervisor/pengawas disebut penjamin mutu pendidikan. Menurut Tamrin (2017) supervisi sangat penting dalam upaya peningkatan kemampuan mengajar guru, namun banyak guru yang kurang menyukai kegiatan supervisi. Ketidaksukaan guru disupervisi pada umumnya karena supervisi selama ini cenderung berdampak psikologis kepada mereka. Guru merasa tidak terbantu, bahkan ada kecenderungan supervisi menjadi beban. Selama ini supervisi masih sering tidak menyelesaikan masalah secara efektif karena metode atau strateginya kurang efektif. Balikan atau refleksi dalam supervisi masih dominan bersifat pengarahan bahkan instruktif, bukan melalui pemberian contoh atau model yang baik.

Rumusan masalah yang disampaikan penelitian ini adalah Dapatkah supervisi klinik membantu meningkatkan kemampuan guru-guru melaksanakan proses pembelajaran di yang baik dan benar mulai pembelajaran pendahuluan, pembelajaran inti dan pembelajaran penutup. Sedangkan tujuannya adalah Untuk mengetahui apakah supervisi klinik dapat membantu guruguru SD Negeri 1 Blahbatuh dalam meningkatkan kemampuan mereka melaksanakan proses pembelajaran yang baik dan benar mulai pembelajaran pendahuluan, pembelajaran unit dan pembelajaran penutup.

\section{Metode}

Penelitian yang dilakukan termasuk jenis penelitian tindakan. Penelitian tindakan ini terfokus pada penelitian tindakan sekolah. Salah satu contoh penelitian tindakan adalah desain yang dibuat oleh Ebbut (dalam Sukidin, dkk., 2002) seperti terlihat pada gambar berikut. 


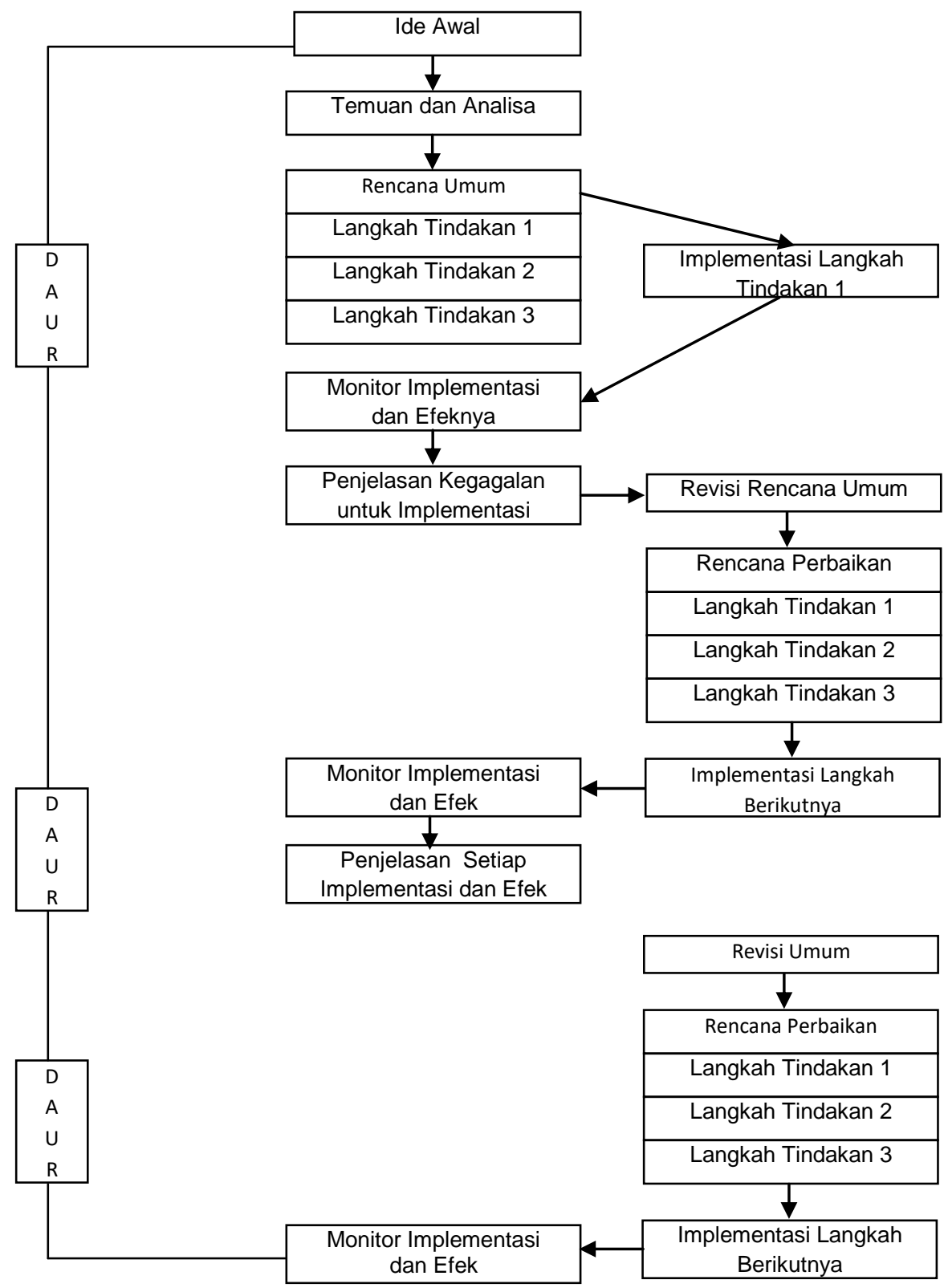

Gambar 1. Desain Penelitian Tindakan Model Ebbut

Disain yang diberikan oleh Ebbut di atas siklusnya sampai 3. Namun dalam penelitian ini hanya digunakan dua siklus dan mengikuti model penelitian yang diberikan oleh Direktorat Jendral Peningkatan Mutu Pendidik dan Tenaga Kependidikan (2008) yang langkahlangkahnya dapat dilihat pada gambar berikut.

Penelitian ini dilaksanakan di kepada guru-guru SD Negeri 1 Blahbatuh yang berjumlah 11 orang. Sedangkan Objeknya adalah peningkatan kemampuan guru-guru dalam melaksanakan proses pembelajaran.

Metode yang digunakan untuk mengumpulkan data adalah mengikuti langkah-langkah yang digunakan dalam supervisi klinik. Untuk menguji hipotesis penelitian ini dicocokan dengan indikator-indikator keberhasilan penelitian yaitu pengisian lembar observasi penelitian tugas guru. Apabila indikator indikator keberhasilan belum tercapai, maka penelitian ini belum bisa dikatakan berhasil ,dan dilanjutkan ke proses berikutnya, apabila hasil yang diperoleh sudah memenuhi kriteria keberhasilan penelitian, maka penelitian ini tidak dilanjutkan ke siklus berikutnya. 


\section{Hasil Dan Pembahasan}

Melaksanakan proses pembelajaran tidak terlepas dari kemampuan guru memahami apa yang mereka mesti lakukan dengan baik yang meliputi keterampilan dasar mengajar. Keterampilan dasar mengajar guru dalam melaksanakan pembelajaran ada 7, yaitu: 1) keterampilan bertanya, 2) keterampilan memberi penguatan, 3) keterampilan mengadakan variasi, 4) keterampilan menjelaskan, 5) keterampilan membuka dan menutup pelajaran, 6) keterampilan membimbing diskusi, 7) keterampilan mengelola kelas, keterampilanketerampilan ini berhubungan dengan kammpuan guru untuk menguasai dasar-dasar pengetahuan yang berhubungan dengan persiapan dan pelaksanan proses pembelajaran yang akan memberikan dukungan terhadap cara berpikir siswa yang kreatif dan imaginatif. Hal inilah yang menunjukkan profesionalisme guru (Wardani dan Jualeha, Modul IDIK 4307: 1-30).

Dalam pelaksanaan pembelajaran tentu ada banyak hal yang mesti dilakukan oleh peneliti selaku pengawas dan juga selaku evaluator. Cakupan hal-hal yang mesti dicek dalam pelaksanaan proses pembelajaran sudah barang tentu mulai dari perencanaan program yang dibuat, yaitu Rencana Pelaksanaan Pembelajaran, perencanaan materi yang akan disampaikan, perencanaan metode dan teknik yang akan dilakukan, perencanaan penilaian serta pembuatan perencanaan analisis dan tindak lanjut. Semua hal yang disampaikan tersebut merupakan bagian yang tidak dipisahkan dari kemampuan guru melaksanakan proses pembelajaran yang baik. Tanpa perencanaan yang baik mustahil seorang guru dapat melaksanakan proses pembelajaran yang baik. Penelitian ini akan sangat berguna sebagai informasi bagi pengambil keputusan. Menurut Stufflebeam yang dikembangkan oleh Worthen et.al. (1997: 98) evaluasi model ini merupakan suatu proses menggambarkan, memperoleh dan menyediakan informasi yang berguna untuk menilai alternatif keputusan menilai atau mengevaluasi kegiatan guru baik dalam pelaksanaan proses pembelajaran dan semua aspeknya yang telah disampaikan maupun dalam kegiatan yang lainnya di sekolah merupakan tugas pengawas sekolah, sehingga upaya ini merupakan satu hal yang sangat mulia dalam upaya peningkatan mutu proses pembelajaran yang dilakukan guru-guru.

Daryanto (2005: 84) mengatakan bahwa supervisi adalah aktivitas menentukan kondisi/syarat-syarat yang esensial yang akan menjamin tercapainya tujuan pendidikan. Salah satu supervise yang dapat diterapkan di sekolah adalah supervise klinik. Shane dan Weaver 1976 (dalam Mantja, 2005) menjelaskan bahwa supervisi klinik adalah sistim penunjang profesional. Sistim itu dapat mendorong perkembangan komponen personal, sosial, akademik dan pola pikir guru untuk memperbaiki serta meningkatkan instruksionalnya dan sekaligus juga meningkatkan pengetahuan dan keterampilan siswanya di kelas. Masih dalam Mantja (2005) mengatakan bahwa supervisi tahap supervisi klinik dimulai dengan pertemuan awal, observasi dan pertemuan balikan. Flanders (1976) melihat supervisi klinik dari aspek analisis interaksinya: supervisi klinik adalah kasus khusus pengajaran dimana sekurang-kurangnya ada dua orang yang memiliki kepedulian terhadap perbaikan pengajaran, dan sekurang-kurangnya salah seorang diantaranya adalah guru yang kinerjanya perlu diperhatikan dan dikaji secara cermat.

Berdasarkan penelitian yang telah dilakukan dengan menerapkan supervise klinik terhadap guru-guru SD Negeri 1 Blahbatuh, didapatkan hasil sebagai berikut.

1). Hasil yang diperoleh dari kegiatan awal:

Deskripsi yang dapat disampaikan untuk perolehan data awal sebagai indikator yang dituntut yaitu minimal guru mampu mencapai ketuntasan belajar dengan nilai sama atau melebihi Ketuntasan namun pada data awal guru-guru SD Negeri 1 Blahbatuh masih jauh dari harapan. Indikator keberhasilan pada penelitian ini yaitu guru-guru diharapkan mampu meraih nilai kuantitatif $A$ atau rata-rata berada pada rentang antara 86-100. Data yang diperoleh menunjukkan nilai klaksikal yang diperoleh sebesar 770 dengan rata-rata hanya mencapai 48,12. Rata-rata yang diperoleh berada antara rentang 66-75 ini artinya nilai kuantitatif yang diperoleh adalah $C$ (Cukup). Pada data ini tidak ada guru yang mendapat nilai kuntitatif $A, 2$ Guru mendapat tergolong nilai kuantitatif $B, 9$ orang guru memperoleh nilai $C$ dan sisanya memperoleh nilai $D$. Data tersebut menunjukkan rendahnya kemampuan guru SD Negeri 1 
Blahbatuh dalam melaksanakan pembelajaran. Kekurangan yang ada adalah akibat proses pembelajaran yang dilakukan oleh guru masih bersifat konvensional. Kelebihannya adalah peneliti sebagai pengawas telah giat melakukan supervisi secara maksimal.

2). Hasil pada siklus I:

Perkembangan kemampuan guru pada siklus I adalah ada 1 orang guru yang memperoleh niali $A, 9$ orang guru yang memperoleh nilai $B$, dan sisanya adalah memperoleh nilai C. Nilai klasikal yang diperoleh adalah 910 dengan rata-rata mencapai 56,87 dengan kualifikasi B yang berada pada rentand 76-85. Data tersebut menunjukkan nilai yang diperoleh sudah mengalami peningkatan namun belum maksimal dan perlu dilanjutkan dengan tndakan berikutnya.

\section{3). Pada siklus II,}

Perkembangan kemampuan guru pada siklus II adalah mengalami peningkatan yang signifikan. Ada 6 guru yang memperoleh kualifikasi nilai $A$, dan sisanya 5 orang guru memperoleh kualifikasi nilai B. Nilai klaksikal yang diperoleh mencapai 980 dengan rata-rata 61,25 dengan kualifikasi nilai A. Data tersebut menunjukkan proses pembelajaran sudah berjalan maksimal karena semua guru sudah mampu mencapai kriteria usulan kinerja yang diharapkan yaitu nilai rata-rata 80 dengan kualifikasi klaksikan antara rentang 86-100 atau A (amat baik) sehingga penelitian ini tidak perlu dilanjutkan dengan tndakan berikutnya.

Semua hasil yang diperoleh dari awal, siklus I dan siklus II dipaparkan dalam bentuk tabel dan grafik seperti berikut.

Tabel 1. Hasil Penilaian Kemampuan Guru Melaksanakan Proses Pembelajaran

\begin{tabular}{|c|c|c|c|c|}
\hline Data & Awal & Siklus I & Siklus li & Variabel \\
\hline Skor Nilai & 770 & 910 & 980 & Usulan kinerja \\
\hline Rata Rata Kelas & 48,12 & 56,87 & 61,25 & diharapkan adalah rata- \\
\hline $\begin{array}{l}\text { Prosentase } \\
\text { ketuntasan }\end{array}$ & $70 \%$ & $82.72 \%$ & $89.09 \%$ & $\begin{array}{l}\text { rata klaksıkal mencapa } \\
86-100 \text { dengan kriteria } \\
\text { "Amat Baik" }\end{array}$ \\
\hline
\end{tabular}

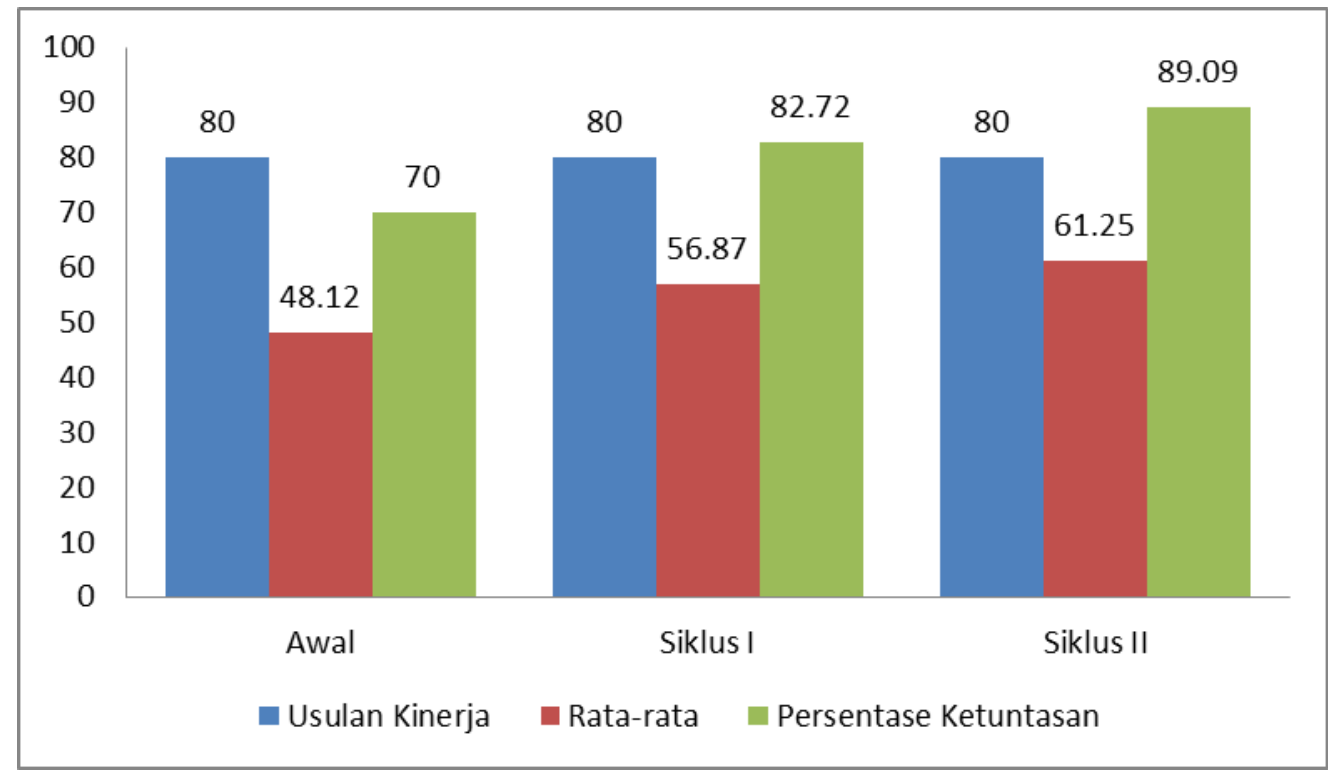

Gambar 2. Hasil Penilaian Kemampuan Guru Melaksanakan Proses Pembelajaran 
Hasil penelitian ini sejalan dengan hasil penelitian yang dilakukan oleh Yulia, dkk pada tahun 2016, yang berjudul Implementasi Supervisi Klinis Dalam Meningkatkan Profesionalisme Guru. Hasil penelitian menunjukkan implementasi supervisi klinis yang dilaksanakan dalam tiga tahap yaitu tahap perencanaan, tahap pelaksanaan, dan tahap umpan balik telah berjalan dengan baik dan dapat meningkatkan profesionalisme guru. Berbagai upaya peningkatan dan pengembangan profesional guru telah diusahakan, seperti penguasaan materi, pemilihan metode pembelajaran, dan media yang digunakan.

\section{Simpulan dan Saran}

Dari data yang diperoleh dapat disimpulkan bahwa: Untuk guru-guru di SD Negeri 1 Blahbatuh, ternyata supervisi klinik dapat meningkatkan kemampuan mereka dalam melaksanakan proses pembelajaran dengan baik. Secara ringkasnya analisis kuantitatif sudah membuktikan bahwa kemampuan guru-guru dari awal ke akhir siklus I meningkat baik walaupun ada kategori-kategori yang belum terpenuhi. Kemampuan guru-guru memang betul sudah meningkat setelah dicoba melihat dari validitas internal, ekternal dan reliabilitasnya. Dari reliabilitasnya, para informan sudah diupayakan dipilih orang-orang dekat guru-guru untuk ditanyai tentang keberadaan guru-guru. Validitas eksternalnya dicek melalui landasanlandasan hukum yang ada, yang sudah dimasukkan dalam perencanaan program di akhir siklus I sedangkan validitas internalnya ditanyakan lewat wawancara dengan kepala sekolah. Bahkan pada siklus I kemampuan guru-guru sudah meningkat. Nilai yang semula rata-rata 48,12 meningkat menjadi 56,87 dan pada akhir siklus II meningkat lagi menjadi 61,25. Akhirnya untuk dapat lebih gampang melihat peningkatan kemampuan guru-guru dalam melaksanakan proses pembelajaran yang baik, di bawah ini disampaikan tabel ringkasan peningkatan kemampuan mereka. Tabel ini sekaligus untuk menjawab rumusan masalah yang diajukan.

\section{Daftar Rujukan}

Anitah, Sri, Julaeha, Siti, dan Wardani, K.A. 2009. Strategi Pembelajaran di. SD. Jakarta: Universitas Terbuka.

Basrowi dan Sukidin. 2002. Metode Penelitian Kualitatif Perspektif Mikro. Surabaya. Insan Cendikia.

Daryanto, H.M. 2005. Administrasi Pendidikan. Jakarta: PT. Rineka Cipta.

Flanders, N.A. 1976. "Interaction Analysis and Clinical Supervision," Journal of Research and Development in Education, Volume 9 (2), Athens, Georgia.

Himdani, Suwito Eko Pramono, Awalya, Himdani. 2017. Pengembangan Model Supervisi Klinis Teknik Konseling Kelompok pada Guru BK SMA Kabupaten Lombok Timur. Educational Management Vol. 6 No. 1 Hal. 1 - 8. Tersedia Pada : http://journal.unnes.ac.id/sju/index.php/eduman.

Mantja, W. 2005. Etnografi Disain Penelitian Kualitatif dan Manajemen Pendidikan. Malang: Wineka Media.

Sujanto, 2007. Psikologi Perkembangan. Jakarta: Rineka Cipta.

Tamrin. 2017. Pengaruh Penerapan Supervisi Akademik Berbasis Modeling Inspiratif Terhadap Peningkatan Kemampuan Mengajar Guru SD Gugus IV Kecamatan Makassar Kota Makassar. JIKAP PGSD: Jurnal IImiah IImu Kependidikan Vol,1. No,2. Hal. 115-127. Tersedia Pada : http://ojs.unm.ac.id/JIKAP/article/view/5284. 
Tanama, Yulia Jayanti, Achmad Supriyanto, Burhanuddin. 2016. Implementasi Supervisi Klinis dalam Meningkatkan Profesionalisme Guru. Jurnal Pendidikan, Vol. 1, No. 11, Hal. 2231-2235. Tersedia Pada : http://journal.um.ac.id/index.php/jptpp/article/view/8127.

Tjokroamidjojo, Bintoro. 2001. Pengantar Administrasi Pembangunan. Jakarta: LP3ES.

Umaedi, Hadiyanto, Siswantari, 2009. Manajemen Berbasis Sekolah, Jakarta: Universitas Terbuka.

Yulia, dkk. 2016. Implementasi Supervisi Klinis Dalam Meningkatkan Profesionalisme Guru. Jurnal Pendidikan: Teori, Penelitian, dan Pengembangan Volume: 1 Nomor: 11 Bulan November Tahun 2016 Halaman: 2231-2235. 